\title{
Extended galleries above the porch in two mosques: Qualitative analysis of mosques with wooden minaret in Bosnia and Herzegovina
}

\author{
Edin Jahić ${ }^{*}$ \\ ${ }^{\mathbf{1}}$ Architecture Department, International University of Sarajevo, Bosnia
}

*Corresponding author: ejahic@ius.edu.ba

Amo Author(s)
Published by ARDA.
hip roof with an integrated wooden minaret. Although they originate in the long
tradition of Turkish single-space mosques, their appearance and construction
represent the expression of Bosnian autochthonous architecture. They were
mostly built for the needs of the neighborhood (mahala) in smaller and larger
towns, but also in rural areas. Due to the perishable materials and various other
reasons, they had been renovated several times so changes in appearance were in
some cases quite certain. These structures have been insufficiently researched and
very few valuable publications are available so far. Qualitative analysis of
significant examples, in addition to the common features by which these mosques
differ from large monumental mosques, differences in the spatial concept, as well
as the construction of individual elements, were observed. Concerning the shape
of the entrance, these mosques have four characteristic solutions: a mosque with a
porch, with a porch and a gallery, without a porch, and with a closed vestibule.
The analysis also showed that the two mahala mosques in Tuzla had a specific
gallery form that deviated from the typical solution. These galleries are extended
over the porch on three sides by the application of ingenious carpentry solutions
and covered with elongated eaves. In addition, this study showed that thanks to
available sources, it was possible to re-establish the original form of the two
mosques, which had since been altered.
and

Keywords: : Mahala mosque, Wooden minaret, Wooden porch, Extended gallery

\section{Introduction}

During the Ottoman rule of Bosnia and Herzegovina (1463-1878), many buildings were built for religious, educational, commercial, and other purposes. To date, only several the most precious monuments have remained. Most of them are mosques, followed by bridges, parts of fortifications, and a small number of other structures. Some historic types, such as madrasas, caravanserais, or hammams, have long since lost their original purpose and significance. The few remaining monuments are used nowadays for cultural or commercial purposes. However, the only type of building of the Ottoman past that has kept its function unchanged is the mosque. Unlike the domed mosques that typically dominate towns, there were a decent number of small neighborhood mosques built across the country. These authentic structures are modest in size and proportions, but appreciated for their authenticity and environmental compatibility. While the monumental mosques are recognized by domes, portals and high minarets, small neighborhood mosques are distinguished by a wooden porch and a hipped roof with a distinctive wooden minaret. According to 1933 statistics, these mostly wooden buildings exceeded the number of monumental domed mosques [9].

This work is licensed under a Creative Commons Attribution License (https://creativecommons.org/licenses/by/4.0/ ) that allows others to share and adapt the material for any purpose (even commercially), in any medium with an acknowledgement of the work's authorship and initial publication in this journal. 
Since that time, many causes have contributed to their continued decline. Many of them were neglected under the socialist regime, and devastated by the 1992-95 war. As they were built of perishable materials (wood, mud-brick, rubble), a number of these structures continuously ruin because of the lack of maintenance, unprofessional repairs, but also communities' intention to build a new mosque. Due to long-term use, changing weather conditions and deteriorating materials, many small wooden mosques require regular repairs or comprehensive renovations.

This study examines and compare several examples of a small wooden neighborhood mosque in Bosnia and Herzegovina, with the reference on two mosques in Tuzla, dating back to the late sixteenth and early seventeenth centuries. They were juxtaposed regarding common and specific spatial features.

\section{Defining of form typology: Mosques with pitched roof}

In comparison to a smaller number of monumental domed structures, the most of mosques are covered with pitched roof. According to architectural characteristics, pitched roof mosques are far more regionally differentiated [9]. The roof shape, pitch, and a roofing material, are closely related to a local tradition. Roofing with stone tiles prevails in Herzegovina; curved clay tiles (ćeremit) are typical in Sarajevo region; while the

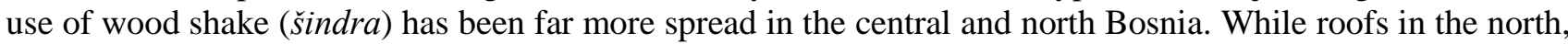
as well as in higher areas of Bosnia, can be recognized by steep slope and deep eaves, by moving to the south, they tend to be lower, both with shorter, or even with no eaves at all. The roof is typically a hip, but rarely a pyramidal form. The unique hip form that covers both prayer space and adjoined porch prevails (Fig. 1).

The mosques with pitched roof are further classified according to minaret type and form. Apart from those with stone minaret mosques and masjids with wooden minaret are smaller, but far more numerous. The typical wooden minaret in Bosnia and Herzegovina consists of a polygonal shaft with, more or less, enclosed gallery (sarafa). Standing on the roof base, it rises through the roof slope on the right side. As this type of the mosque was built for a local neighborhood in a town or a village, they are rightly referred to as the 'neighborhood' (mahala) mosques.

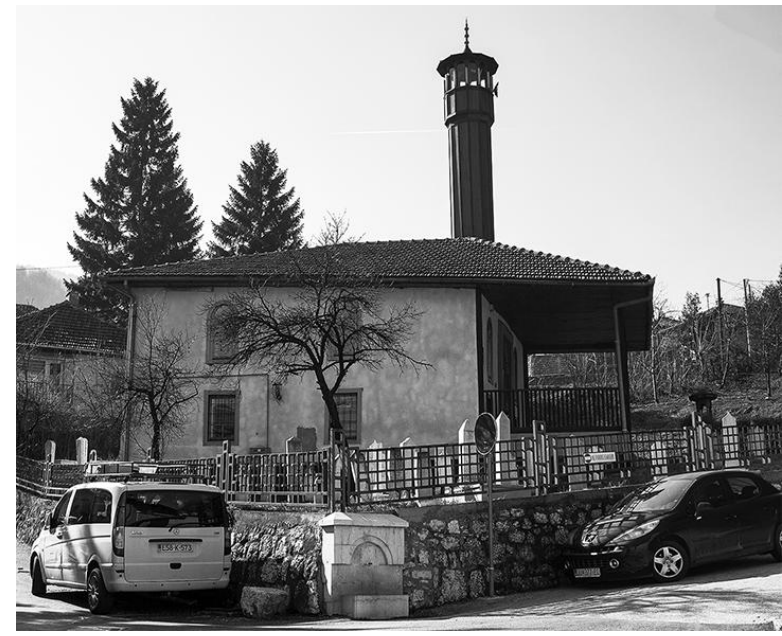

Figure 1. A typical mosque with wooden minaret and porch: Bali-beg Malkoč

Mosque in Sarajevo. Photo by author

Compared to a spacious çarşı mosque, which dominates with accentuated formal elements, such as domes, portals, and tall minarets, the mahala mosque is often smaller in proportions and capacity, and at the same time built to fit into surrounding with white and plain walls, as well as wooden roof and porch. Therefore, in the mahala panorama, only wooden minaret indicates its presence. Considering many such buildings within the tradition that has lasted more than four centuries, Bećirbegović [9] identifies these structures as a specific expression of the domestic building tradition. Although typologically originate from the Ottoman tradition, these structures eventually grew into a typical expression of a regional tradition that fully fits into both urban and rural environments. The founders were mostly local landowners, military commanders, or other wealthy individuals. Unlike monumental Ottoman buildings which were constructed by skilled, usually foreign masons [6], these mosques were built by local builders, called dunđeri (tur. dülger) [2]. These local builders were typically engaged in carpentry, but they were able to perform complete construction, together with a building layout, sizing, and proportions. The mahala mosques with wooden minaret are built of traditional materials: wood, clay (mud) and stone. In the past, the roughly hewn timber was used for the roof and wall 
framing, while the sawn and finished, and sometimes profiled or carved timber, was used for windows, minbar, porch and mahfil beams, stairs, and other visible parts. Out of available wood species, oak, spruce, and pine were the most valued. Typical roof shakes (sindra) were made by hand-splitting softwood with the groove on a single side [11]. Earthen material was used in two forms: as a sun-dried clay brick (ćerpič), and as a clay-based plaster. The wet clay was usually mixed with a sand, chopped wheat straw, and animal hair. Both sun-dried brick walls and timber framing walls were rendered with clay-based plaster. For this purpose, common ingredients were clay, sand, animal hair and quicklime. Wall surfaces were whitewashed, with only few details occasionally decorated with colored paint. If available, rubble masonry was used to build walls as well as foundations. Massive walls were strengthened with horizontal oak tie beams (hatule). All these materials, when exposed to weather and without regular maintenance and repair, decay rapidly, especially clay and wood. Considering that wood prevails both in framing and appearance, this type of mosque is sometimes named as 'wooden' [9].

Mosques with pitched roof and wooden minaret are modest buildings intended for the needs of the neighborhood, built from the late fifteenth century until the end of the Ottoman period, 1878. In addition to common features, such as a unique prayer space of modest dimensions under the hip roof with integrated wooden minaret, the exterior of the mosque is determined by the shape of the porch, or any other form of an entry space (Fig. 2). Regarding the porch and its form, several characteristic types of mahala mosques with wooden minaret can be recognized as:

- The mosque with porch

- The mosque with porch and a gallery

- The mosque without porch

- The mosque with vestibule

The mosque with the porch is the basic type which corresponds entirely to the same type of mosque with pitched roof and stone minaret. It contains a porch with wooden posts supporting the roof. Depending on size, a porch is typically bordered with six to ten, mostly slender posts. This type is common in the central and east Bosnia. The most of the Sarajevo's adobe mahala mosques dating back to the sixteenth century belong to this type [15], but they were also built in Banja Luka [3], Tešanj, Tuzla, Jajce, Srebrenica, and many other places.
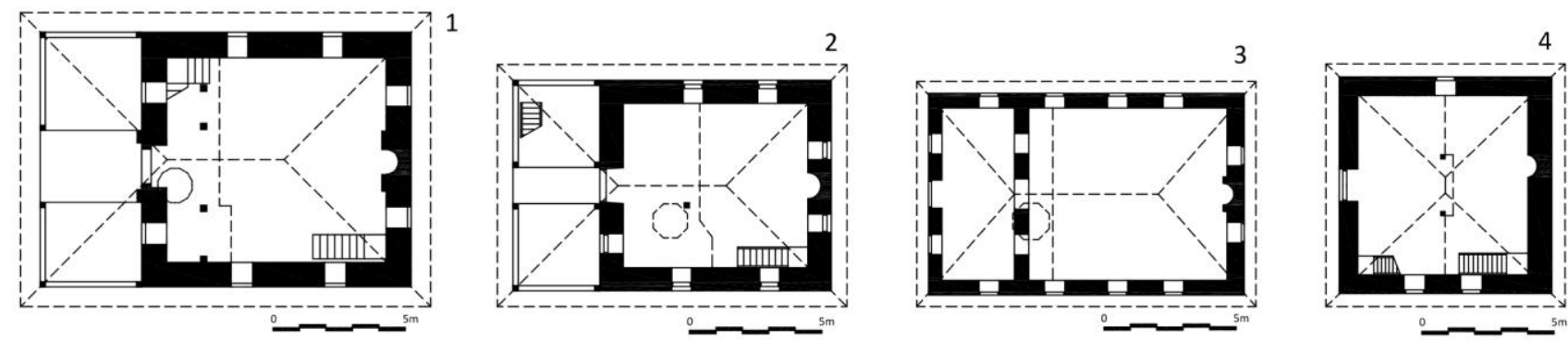

Figure 2. Four characteristic types of mosques with wooden minaret: With porch $\square$

Bali-beg Malkoč Mosque in Sarajevo (1); with porch and a gallery $\square$ Mosque in

Džebari (2); with vestibule $\square$ Konatur Mosque in Travnik (3); without porch -

Mosque in Kušlat (4); Drawing by author

As a need to enlarge the prayer space, wooden porch was also built in two levels. The upper level of the porch can be open on all three sides (gallery), partially closed, or completely walled up as rare case. The gallery is accessed by steep stairs directly from the porch (sofa), or through the mahfil inside the mosque. The timber construction of the gallery is more complex than in the previous type, which can be taken as one of the reasons for the slightly a smaller number of remaining examples. Like the previous type, this type is also present in central and eastern Bosnia.

Mosques without porch were built in exceptional cases, such as the lack of space, or for other reasons. The existing examples are old mosque in Kušlat, Dizdareva Mosque in Jajce, and mosque in Šturlić [9].

Instead of an open porch, there are also mosques with a closed vestibule. The width of the vestibule is equal to the width of the mosque, while the depth is much smaller. There are usually stairs leading to the mahfil. This type is characteristic of western Bosnia, although there are cases in other places as well. Given the individual cases of subsequent walling of porches, it is difficult to determine with certainty which mosques had a porch at the time of construction. The examples are Konatur Mosque in Travnik, Fethiyye mosque in Teočak, Zavra Mosque in Livno, although the last two may be examples of subsequent closure of the porch. Table 1. shows 
typical examples of mosques with wooden minaret in Bosnia and Herzegovina dating from the fifteenth to the nineteenth century.

Table 1. Comparative list of mosques with wooden minaret

\begin{tabular}{|c|c|c|c|c|c|c|}
\hline Mosque & $\begin{array}{c}\text { Time of } \\
\text { construction }\end{array}$ & $\begin{array}{c}\text { Type of } \\
\text { Mosque } \\
\text { in relation } \\
\end{array}$ & $\begin{array}{c}\text { Prayer } \\
\text { room }\end{array}$ & $\begin{array}{l}\text { Porch } \\
\text { depth } \times \\
\end{array}$ & $\begin{array}{l}\text { Gallery } \\
\text { depth } \times\end{array}$ & $\begin{array}{c}\text { Relative } \\
\text { increase of } \\
\text { the total }\end{array}$ \\
\hline $\begin{array}{c}\text { Mosque in Kraljeva } \\
\text { Sutjeska }\end{array}$ & $15^{\text {th }}$ century & $\begin{array}{l}\text { Porch and } \\
\text { a gallery }\end{array}$ & $6,45 \times 8$ & $3,57 \times 7,9$ & $3,57 \times 7,9$ & 1,09 \\
\hline $\begin{array}{l}\text { Bali-beg Malkoč } \\
\text { Mosque in Sarajevo }\end{array}$ & $1475-76$ & Porch & $8,1 \times 8,1$ & $3,9 \times 10$ & & 0,59 \\
\hline Mosque in Kušlat & Before 1481 & No porch & $6,45 \times 6,75$ & & & \\
\hline $\begin{array}{c}\text { Sagr Hadži Ali } \\
\text { Mosque in Sarajevo }\end{array}$ & 1549 & $\begin{array}{l}\text { Porch and } \\
\text { a gallery }\end{array}$ & $8,3 \times 7,7$ & $4 \times 9$ & $4 \times 9$ & 1,13 \\
\hline $\begin{array}{l}\text { Atik Mosque in } \\
\text { Fojnica }\end{array}$ & 1551 & Porch & $7,6 \times 6,8$ & $4 \times 8,7$ & & 0,67 \\
\hline $\begin{array}{l}\text { Ašik Memi Mosque } \\
\text { in Sarajevo }\end{array}$ & 1551 & Porch & $8,2 \times 6,8$ & $2,7 \times 8$ & & 0,39 \\
\hline $\begin{array}{c}\text { Tabak Hadži } \\
\text { Suleiman Mosque in } \\
\text { Saraievo }\end{array}$ & Before 1562 & $\begin{array}{l}\text { Porch and } \\
\text { a gallery }\end{array}$ & $8,7 \times 8,6$ & $2,5 \times 10$ & $3,4 \times 10)^{* *}$ & 0,79 \\
\hline $\begin{array}{c}\text { Džindijska Mosque } \\
\text { in Tuzla }\end{array}$ & $1548-1600$ & $\begin{array}{l}\text { Porch and } \\
\text { a gallery }\end{array}$ & $7,3 \times 6,2$ & $3,7 \times 8,1$ & $4,70 \times 10,1)^{*}$ & 1,71 \\
\hline Mosque in Džebari & $16^{\text {th }}$ century & $\begin{array}{l}\text { Porch and } \\
\text { a gallery }\end{array}$ & $7,0 \times 6,2$ & $3,25 \times 7,9$ & $3,25 \times 7,9$ & 1,18 \\
\hline $\begin{array}{c}\text { Atik Mosque in } \\
\text { Koraj }\end{array}$ & $16^{\text {th }}$ century & Porch & $7,0 \times 6,6$ & $3 \times 8,6$ & & 0,56 \\
\hline $\begin{array}{c}\text { Kethoda Mosque in } \\
\text { Tuzla }\end{array}$ & Before 1600 & Porch & $8,4 \times 7,3$ & $3,3 \times 9$ & & 0,48 \\
\hline $\begin{array}{c}\text { Hasan Kafi Prušćak } \\
\text { Mosque in Prusac }\end{array}$ & 1607 & Porch & $10,8 \times 7,4$ & $2,5 \times 7,4$ & & 0,23 \\
\hline $\begin{array}{c}\text { Sefer Beg Mosque in } \\
\text { Banja Luka }\end{array}$ & Before 1618 & Porch & $8 \times 7,2$ & $4,5 \times 8,6$ & & 0,67 \\
\hline $\begin{array}{c}\text { Behram Efendi } \\
\text { Mosque in Banja } \\
\text { Luka }\end{array}$ & Before 1638 & Porch & $6,7 \times 6,2$ & $3,6 \times 7,4$ & & 0,64 \\
\hline $\begin{array}{c}\text { Mejdanska Mosque } \\
\text { in Tuzla }\end{array}$ & Before 1644 & $\begin{array}{l}\text { Porch and } \\
\text { a gallery }\end{array}$ & $5,5 \times 5,1$ & $1,95 \times 6,7$ & $2,65 \times 8,0)^{*}$ & 1,22 \\
\hline
\end{tabular}




\begin{tabular}{|c|c|c|c|c|c|c|}
\hline Mosque & $\begin{array}{c}\text { Time of } \\
\text { construction }\end{array}$ & $\begin{array}{c}\text { Type of } \\
\text { Mosque } \\
\text { in relation }\end{array}$ & $\begin{array}{c}\text { Prayer } \\
\text { room }\end{array}$ & $\begin{array}{c}\text { Porch } \\
\text { depth } \times\end{array}$ & $\begin{array}{l}\text { Gallery } \\
\text { depth } \times\end{array}$ & $\begin{array}{c}\text { Relative } \\
\text { increase of } \\
\text { the total }\end{array}$ \\
\hline $\begin{array}{c}\text { Sinan Beg Mosque } \\
\text { in Jajce }\end{array}$ & 1682 & $\begin{array}{c}\text { Walled } \\
\text { vestibule }\end{array}$ & $5,8 \times 5,2$ & $3,25 \times 6,1$ & & \\
\hline $\begin{array}{c}\text { Ibrahim Beg Mosque } \\
\text { in Jajce }\end{array}$ & Before 1692 & Porch & $8,0 \times 7,0$ & $3,9 \times 8,4$ & & 0,59 \\
\hline $\begin{array}{l}\text { Atik Mosque near } \\
\text { Tojšići }\end{array}$ & $17^{\text {th }}$ century & $\begin{array}{l}\text { Porch and } \\
\text { a gallery }\end{array}$ & $8,4 \times 8,1$ & $3 \times 8,4$ & $3 \times 8,1$ & 0,74 \\
\hline $\begin{array}{c}\text { Tabhane Mosque in } \\
\text { Visoko }\end{array}$ & $17^{\text {th }}$ century & $\begin{array}{l}\text { Porch and } \\
\text { a gallery }\end{array}$ & $7,2 \times 7,2$ & $4,5 \times 9$ & $4,5 \times 9$ & 1,56 \\
\hline $\begin{array}{c}\text { Avdi-paša Mosque } \\
\text { in Tešanj }\end{array}$ & $17^{\text {th }}$ century & Porch & $9,5 \times 8,0$ & $3,1 \times 9,25$ & & 0,38 \\
\hline Mosque in Šturlić & $17^{\text {th }}$ century & No porch & $11 \times 5$ & & & \\
\hline $\begin{array}{l}\text { Old mosque in } \\
\text { Tuholj }\end{array}$ & $18^{\text {th }}$ century & $\begin{array}{l}\text { Porch and } \\
\text { a gallery }\end{array}$ & $6,5 \times 6,4$ & $2,5 \times 6,4$ & $2,5 \times 6,4$ & 0,77 \\
\hline $\begin{array}{c}\text { Wooden Mosque in } \\
\text { Poljice }\end{array}$ & 1804 & $\begin{array}{c}\text { Walled } \\
\text { vestibule }\end{array}$ & $10 \times 8,8$ & $2 \times 8,8$ & & \\
\hline $\begin{array}{c}\text { Dizdar Mosque in } \\
\text { Jajce }\end{array}$ & 1813 & No porch & $5 \times 4,4$ & & & \\
\hline $\begin{array}{l}\text { Čaršijska Mosque in } \\
\text { Srebrenica }\end{array}$ & Before 1836 & Porch & $6,4 \times 6,4$ & $2,6 \times 8,3$ & & 0,53 \\
\hline $\begin{array}{c}\text { Konatur Mosque in } \\
\text { Travnik }\end{array}$ & Before 1864 & $\begin{array}{c}\text { Walled } \\
\text { vestibule }\end{array}$ & $7,5 \times 6,5$ & $2,7 \times 6,5$ & & \\
\hline $\begin{array}{l}\text { Atik Mosque in } \\
\text { Špionica }\end{array}$ & Before 1870 & $\begin{array}{l}\text { Porch and } \\
\text { a gallery }\end{array}$ & $6,3 \times 6,5$ & $2,8 \times 8,8$ & $2,8 \times 8,8$ & 1,2 \\
\hline $\begin{array}{l}\text { Mosque in Gornja } \\
\text { Seonica, Konjic }\end{array}$ & 1880 & Porch & $6,1 \times 5,7$ & $2,5 \times 6,7$ & & 0,48 \\
\hline
\end{tabular}

* Gallery extended at three sides

** Gallery extended at the front side

The choice of mosque examples was made according to the availability of information. Some buildings have changed their original appearance over time, but have been valued according to their original form. The examples show the presence of all four types. Among the mosques that have a gallery above the porch, only three cases are known in which the galleries had a more complex form. In Sarajevo, only the Tabak Hadži Suleiman mosque had a gallery protruding to the front (Fig. 3). This is known only from the drawings of Josip Pospišil [9], while the current appearance is the result of one of the last reconstructions in which the mosque lost its original appearance. The situation is similar with the two mosques in Tuzla, with their galleries projecting on three sides. As in the case of the Tabak Hadži Suleiman Mosque, these too lost their original 
appearance during one of the reconstructions dating back to the beginning of the twentieth century (Fig. 5). However, during the last reconstructions, their original appearance has been restored (Fig. 6). In addition to a qualitative comparison of selected cases, an analysis of the relationship between closed and semi-closed space was made. The factor of the relative increase of the total prayer space in mosques with a porch, with and without a gallery was calculated. A comparison of the obtained values shows that mosques with galleries have an increase factor greater than 1.0. The largest factor is the Džindijska Mosque (1.71), thanks to the spacious extended gallery. However, although it is a smaller building, the extension of the gallery in the Mejdanska mosque did not significantly contribute to the increase in space (1.22). A specific case is the Tabak Hadži Suleiman Mosque with a value of less than 1.0, although it had an extended gallery on the front. The reason is the small size of the porch compared to the interior. In contrast, on the example of the Tabhane Mosque in Visoko, we see a significant increase although there is no extended gallery (1.56). Therefore, it can be concluded that in the case of the two mosques in Tuzla, a significant increase in space was not the primary reason for the introduction of the extended gallery.

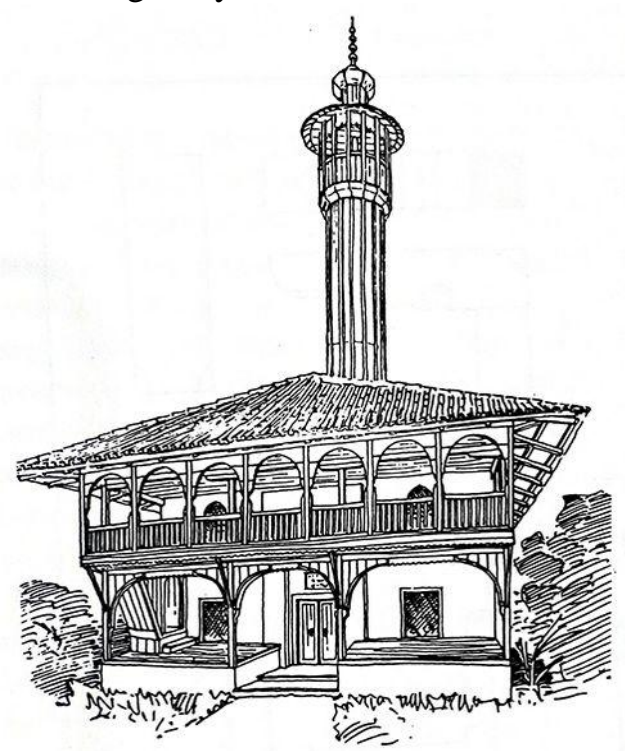

Figure 3. Old image of Tabak Hadži Suleiman Mosque in Sarajevo; Drawing by J. Pospišil

\section{Historical background: Tuzla in the Ottoman period}

The origin of Tuzla relates to saline sources that have been exploited since the Roman time. The exploitation of salt springs in the Ottoman period, initiated the development of two qasabas ("Towns") - Gornja Tuzla and Donja Tuzla [1]. This region was part of the Zvornik Sanjak, the Ottoman administrative unit established between 1477 and 1483. Comparing to nearby towns, such as Zvornik, Gračanica, Brčko, or Bijeljina, Donja Tuzla developed faster, what finally contributed to moving the seat of mutesarrif (governor) from Zvornik to Tuzla in 1851 [1].

Before the Turkish conquest, the late medieval town Sol (Donja Tuzla) was fortified with wood, and for the first time it was referred in the Ottoman sources from 1463 as Agaç Hisar ("Wooden Town") [1]. Compared to stone fortified medieval towns in region, such as Zvornik, Teočak, and Srebrenik, Donja Tuzla was the only one which was named as "wooden". Although it was a prominent place in the northeast Bosnia, it has never had a monumental Ottoman structure. Reasons can be searched within political, economic, or material circumstances. However, one of the obvious arguments may be the lack of a nearby quality quarry, and consequently the underdeveloped tradition of stone-masonry. In addition, it is certain that the Tuzla region was abundant with forests, so the carpentry craft has advanced considerably.

The qasaba Donja Tuzla was continuously expanding since the beginning of the sixteenth century. Thus, at the end of the century, it consisted of nine mahalas, while additional three developed at the beginning of the seventeenth century. Their origins and titles are associated with a founder of the mosque or masjid, around which the settlement grew up. Before the end of the sixteenth century, there were seven mosques and one masjid, while three mosques and one masjid were built before 1644 [1]. Each of buildings were covered with wooden pitched roof. We can be sure that merely three mosques were built with a stone minaret before 1600 . 
Due to large-scale reconstructions in nineteenth century, none of these three mosques preserved its early form [12]. Out of a total of twelve mosques in Donja Tuzla, there were seven mosques and masjids with a wooden minaret and porch. They were modest in size, having thick mud-brick walls, and wooden porch in front of the entrance. Four of them were pulled down from 1945 to 1957 [12]. Today, only three buildings with wooden minaret and porch exist in Tuzla. The Džindijska Mosque and the Mejdanska Mosque were lately restored, and are subjects of this study.

The oldest mosque in Donja Tuzla was built soon after 1533 in the Atik ${ }^{1}$ mahala. The prominent location at the highest place in the center of the town indicates indisputable value of the mosque, which is, in early records, mentioned as Časna ("The honorable") Mosque. Since no name is linked to it, it can be considered to have been built from state funds for the needs of the crew and a small Muslim population. No reliable sources give precise information on its appearance. However, there is an assumption that the first mosque in Donja Tuzla, was likely built of mud-brick and wood, and with no minaret [12].

The sources on early mosques in wider region of Tuzla are very scarce. According to Handžić [1], soon after the Ottoman conquest, earliest mosques were built in captured fortresses for the needs of the military crew. Those were state mosques used and maintained by soldiers. They existed in Zvornik, Srebrenica, Kušlat, Teočak, Sokol and Srebrenik [1]. The only surviving structure is the mosque in Kušlat, ${ }^{2}$ the medieval fortress south of Zvornik. It is assumed that the mosque was erected between 1460 and 1480 [1]. It stands on a high cliff visible from several positions. Almost square in plan, this austere and authentic structure is topped with very steep roof, together with wooden minaret which rises at the top. Inside the mosque, there is a spacious wooden mahfil resting on two posts.

Apart from the early structures within fortifications, mosques with wooden minarets were founded in many towns and villages of north-east Bosnia. Unfortunately, most of them are not systematically documented and valorized. According to the statistics from 1933, which is discussed by Bećirbegović [9], there were a total number of 258 mosques in the Tuzla muftiate area. ${ }^{3}$ Only $41(16 \%)$ were built with stone minaret, while 205 (84\%) mosques had wooden minaret. If we consider a total number of 93 half-ruined and 32 ruined mosques in the same area, there were only $133(51,5 \%)$ in a 'solid' condition. Since no later information on these mosques is available, it is not possible to presume how many exist today. The periods of war destruction, firstly during World War II, and especially the last 1992-95 war, but also many other reasons contributing to the poor maintenance or disappearance of this part of the built heritage, all resulted in a significant reduction in their number and authenticity. The remaining mosques were maintained or rebuilt at the initiative of their users and with donor funds. Some of them have been under the formal protection of state agencies for decades, such as Fethiyye Mosque in Stari Teočak. The others got a status of protected cultural monument after the 1992-95 war. The examples are old mosques in Špionica (Srebrenik) and Tuholj (Kladanj), both in north-east Bosnia.

\section{Two mosques with specific features in Tuzla}

The two small mahala mosques in Tuzla contain basic features that are common to other mosques of the same type, but in addition to these, they also exhibit peculiarities that are not recognized in many others. The Džindijska Mosque (tur. Cindi) and the Mejdanska Mosque (tur. Meydan) belong to the type with a porch and gallery dating from the late sixteenth and early seventeenth centuries. Each has been reconstructed and refurbished several times, changing the previous appearance. Recent reconstructions have restored a much more appropriate appearance. Except old photos and aquarelle sketch, no sound information on their earlier look is available. Comparing these two buildings with each other as well as with similar examples, both in Tuzla itself and in other parts of Bosnia and Herzegovina, it is possible to notice a unique expression and characteristics.

The Džindijska mosque was built in the mahala of the same name, developed shortly before the end of the sixteenth century by certain Mustafa Džindija [1]. The mosque was typically situated at the crossing of mahala roads. Its outside dimensions are approximately $12,5 \times 8 \mathrm{~m}$, consisting of the prayer room $7,3 \times 6,15 \mathrm{~m}$ and the porch 3,65 m deep (Fig. 4-1). Walls are built of mud-brick (ćerpič; tur. kerpiç) slightly tapering towards the top on either side. There are sixteen windows, four at each side. The lower windows are rectangular, while the

\footnotetext{
1،Old" in Ottoman Turkish

${ }^{2}$ After destroyed by the Serbian army in 1993, the mosque was restored in authentic form in 2011-13.

${ }^{3}$ The area of Tuzla Mufti in 1933 approximately match the northeast Bosnia and Herzegovina. It consisted of: Bijeljina, Brčko, Gračanica, Gradačac, Kladanj, Maglaj, Srebrenica, Tuzla, Vlasenica and Zvornik.
} 
upper ones are narrower with slightly pointed arch (ćemer; tur. kemer). The entrance arched door is framed with plain tall portal. The similar portal frames the rounded mihrab. The interior wooden gallery (mahfil) is set up alongside the entrance wall. It is supported by side walls and two timber posts. There are a very steep and narrow stairs at the right side to climb up on it. There is no decoration within the mosque or at the exterior.
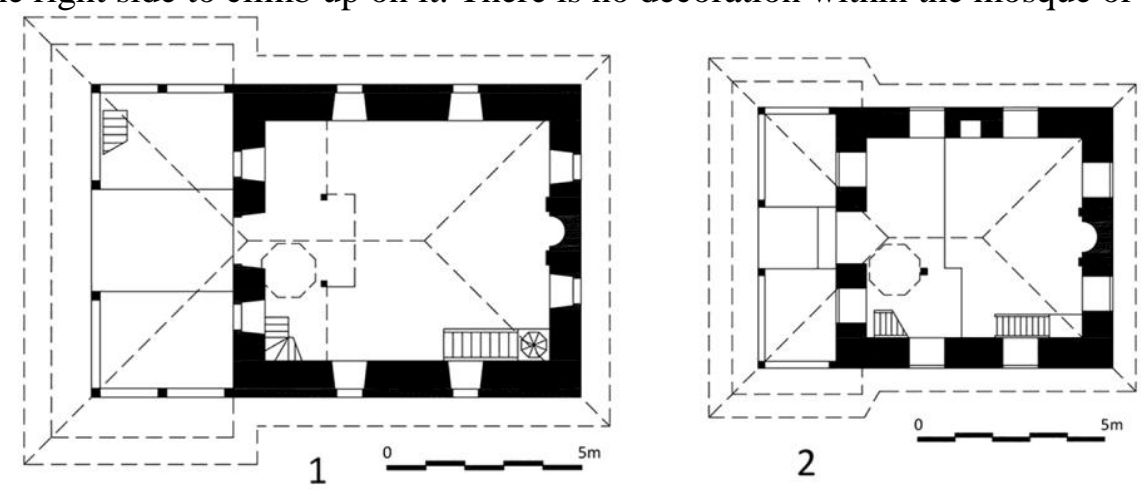

Figure 4. Floor plans of two mosques with extended galleries: Džindijska Mosque

(1) and Mejdanska Mosque (2); Drawing by author

The wooden porch consists of eight posts supporting the exterior gallery and the roof. At the ground level, two side raised platforms (sofa) serve as the additional summer prayer space (tur. son cemaat yeri). A unique feature is the gallery, which is extended over the porch on all three sides, measuring in total $10 \times 4,6 \mathrm{~m}$. The gallery cantilevers are supported by inclined bracing timbers (ćustek; tur. köstek). The lower ends of the braces have a foothold in the porch pillars. A very steep bonnet roof covers the mosque along with the porch. The roof is covered with traditional hand-split shakes. The minaret is $1,35 \mathrm{~m}$ wide and rises from the roof base and ends up above the ridge. Currently is lined with board. The shaft ends with closed and slightly wider gallery ( $\check{s e r e f e}$; tur. şerefe) with small openings at each side. The šerefe is topped with pyramidal roof cap clad with sheet metal.

The oldest known record of its appearance was made at the very end of the nineteenth century. In his brochure from 1899, "The Folk House in Bosnia and Herzegovina" [13], Rudolf Meringer brought aquarelle paintings with plans of several mahala mosques in Tuzla (Fig. 5). The image of the Džindijska Mosque shows extended gallery over the porch. Both gallery and roof eaves are supported by inclined bracing timbers (čustek). Another valuable source, probably of the later date, is an image shot by unknown photographer which shows the Džindijska Mosque including the nearest surrounding (Fig. 7).
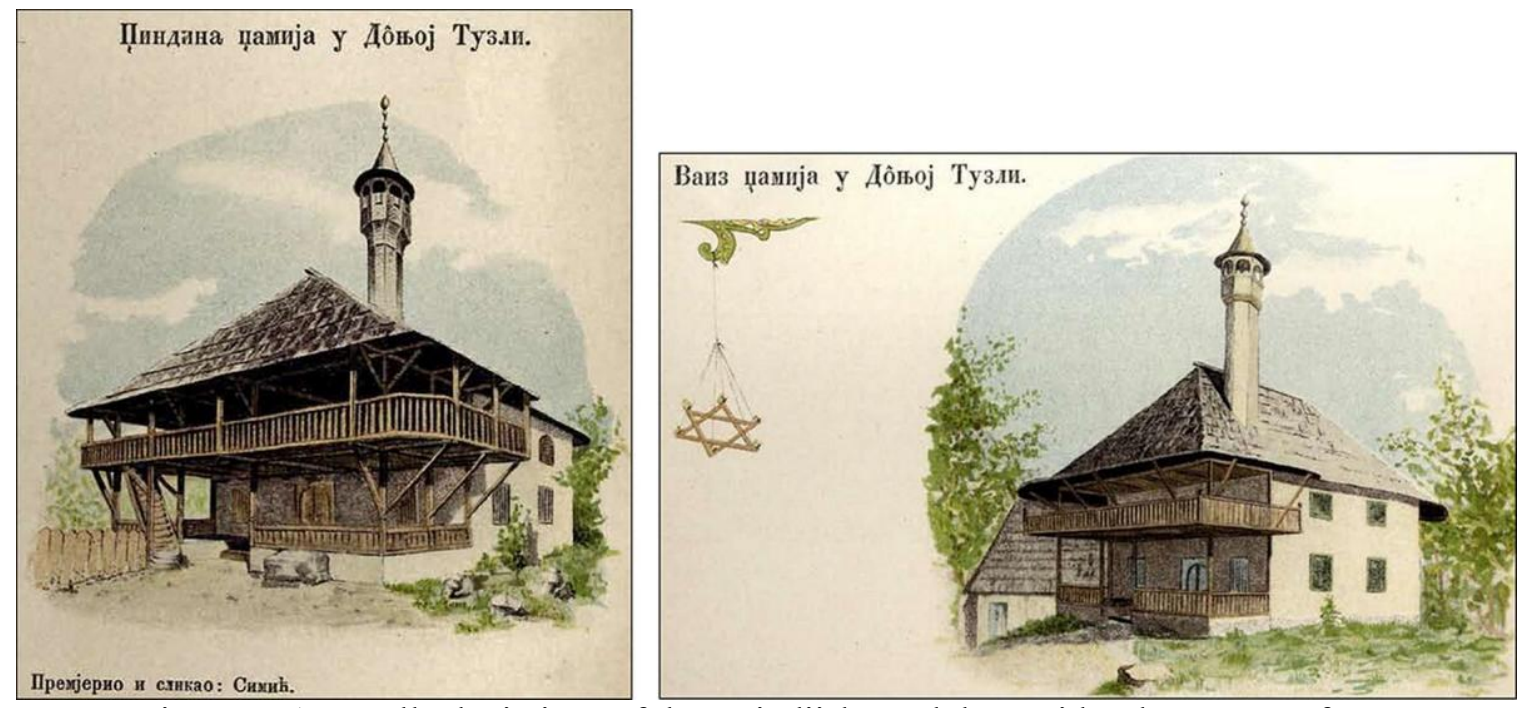

Figure 5. Aquarelle depictions of the Džindijska and the Mejdanska Mosque from the Meringer's brochure; Depictions by Simić

However, the image of the mosque taken before 1982 (Fig. 6), clearly shows changes made in the meantime. The building seemed deteriorated, with no extensions of the gallery above the porch, and with the roof covered with clay tiles. Still, some details of decorative carving on the timber posts were visible. Thanks to 
the initiative of several conscious individuals in Tuzla, this valuable example of vernacular Bosnian architecture has been saved from the final disappearance. ${ }^{4}$ A few years later, the building was completely restored, except mud brick walls which were reinforced and newly rendered. ${ }^{5}$ In addition, the roof was renewed with original roofing material, wood shakes (šindra) (Fig. 8).
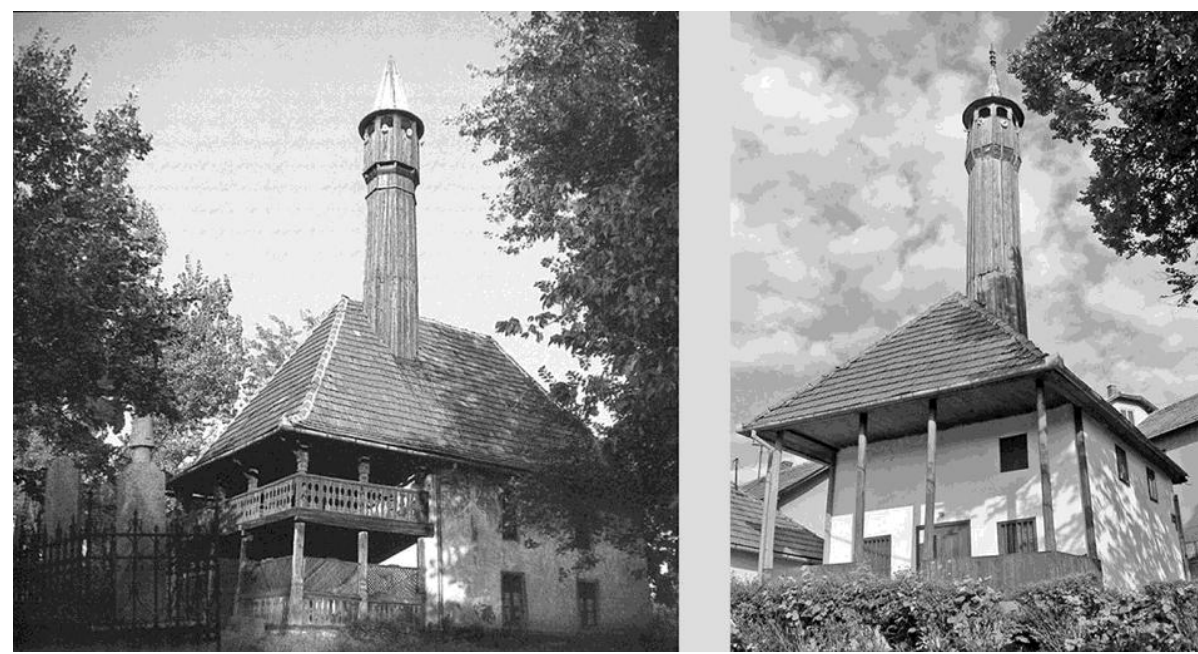

Figure 6. The Džindijska and Mejdanska Mosque before last renovations (before 1982); Photo by: anonymous photographer (left), author (right)

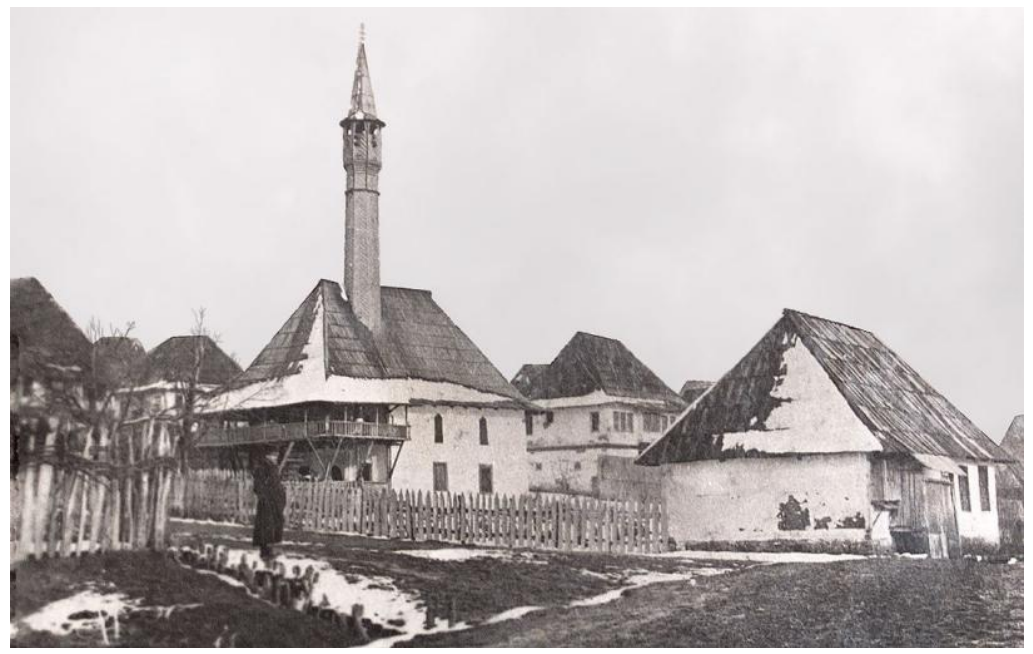

Figure 7. An old photo of the Džindijska Mosque with surrounding mahalle in the end of the $19^{\text {th }}$ or the first decades of the $20^{\text {th }}$ century; Photo by: anonymous photographer

Another example emerged a few decades later when a certain Dželāli Vāiz Mehmed-efendi founded a masjid in Donja Tuzla before 1644 [1]. Later the masjid is mentioned as Vāiz Ali-efendi Mosque in Dželāli, or Mejdan mahala in Donja Tuzla town [1]. Today, it is named as the Mejdanska (Meydan) Mosque. Its location shows typical position of a mosque in a development of mahala in the Ottoman period. The mosque is situated next to the crossing of two roads, on the triangular sloping site together with adjacent sibyan mekteb.

The present mosque is smaller than its predecessor in Džindijska mahala, measuring externally $9,10 \times 6,7 \mathrm{~m}$ (Fig. 4-2). The prayer room is almost square in plan and takes $5,54 \times 5,15 \mathrm{~m}$. Mud brick walls $78 \mathrm{~cm}$ thick contain fifteen windows, four in two levels on each side, except the entrance wall. The mihrab is semi-circular and framed with tall plain portal. The interior mahfil is supported by side walls and a single post. It takes almost half of the prayer room, with a muezzin extension on the right side. Very steep and narrow stairs at the right corner are placed bellow the mahfil. The porch is only two meters deep and consists of six wooden posts supporting the exterior gallery and roof. The sofa is surrounded with low parapet made of wooden board

\footnotetext{
${ }^{4}$ Out of twelve mosques in Tuzla dating from Ottoman period, five were knocked down in fifties of twentieth century [9].

${ }^{5}$ The Republic Institute for the Preservation of the Cultural Heritage Monuments of Socialist Republic of Bosnia and Herzegovina
} 
(parmak). Prior to the last reconstruction in 2005, the appearance of the mosque was different from the current one. As many other mosques in Bosnia and Herzegovina, it had lost the original look during some of previous interventions, probably at the beginning of the twentieth century (Fig. 6). There was no gallery above the porch at all. During the last reconstruction, the mosque was restored to its previous appearance with a protruding gallery and a suitable roof shape (Fig. 8).

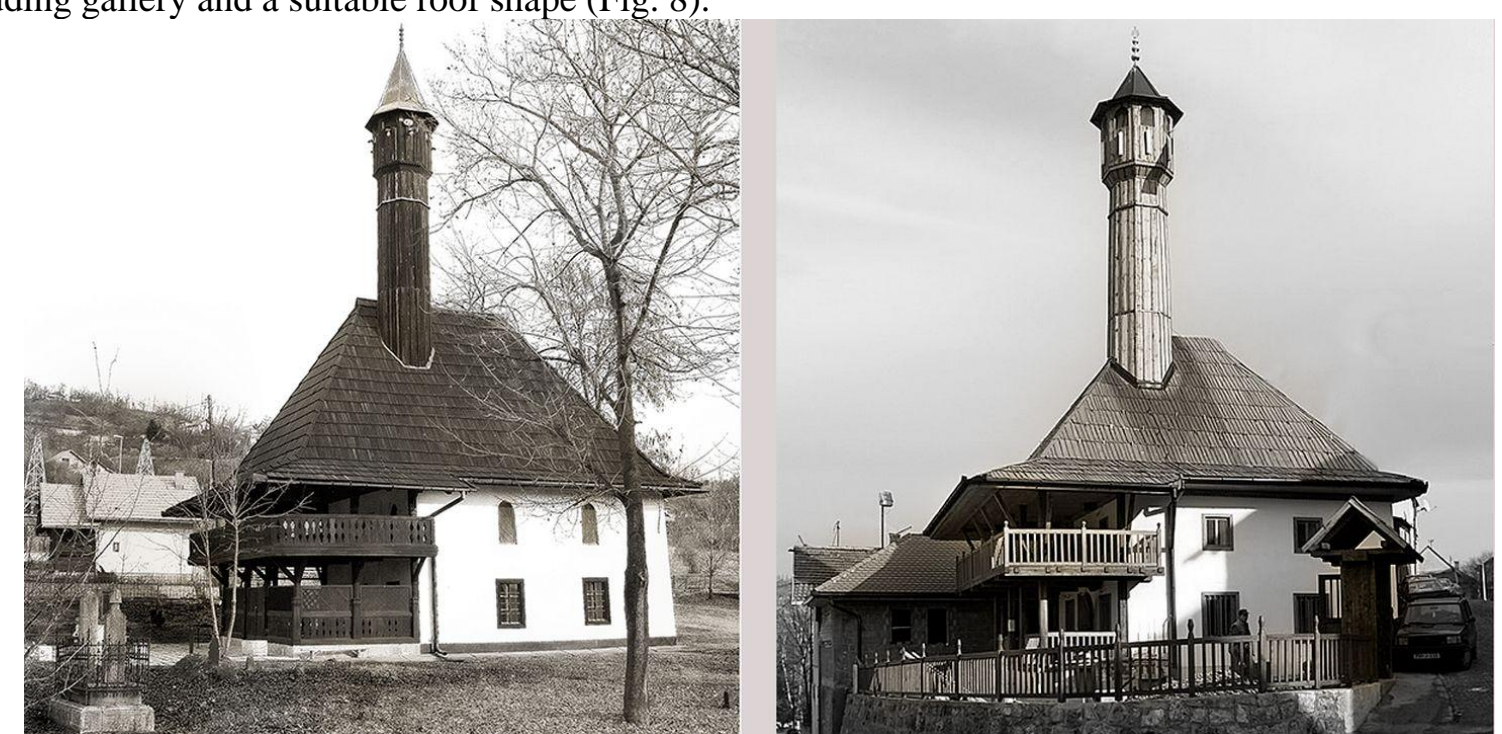

Figure 8. Two mosques after the renovation: The Džindijska Mosque (around 1982), and the Mejdanska Mosque (2005). Photo by: Mustafa Terzić (left); author (right)

In terms of typology, construction materials and shapes, the two mosques in Tuzla share common characteristics with numerous similar mosques in Bosnia and Herzegovina. Thanks to old drawings and photographs, it was possible to establish the previous appearance, which is certainly much closer to the original. In Meringer's aquarelle depictions [13], the construction of the extended galleries on three sides is clearly visible (Fig. 5). In the picture of the Džindijska mosque, the ends of the gallery were additionally supported by long oblique timbers that rest on the pillars. To have the galleries protected from the rain, it was logical to protrude the roof ends as well. Since both mosques had a steep roof, the protruding eaves would make the gallery too close and lightless. To avoid such situation, the carpenter simply lowered the slope of the eaves, extended them a little, and additionally supported them with short oblique beams (čustek; tur. köstek). In addition, light posts supporting the eaves were placed along the gallery fence. Unlike the Džindijska Mosque, the picture of the Mejdanska clearly shows the lack of oblique timbers supporting the gallery. This might be logical because of much smaller depth of the gallery. However, the carpenter in this case also 'broke' the eaves and extended it to protect the gallery. Compared to the Džindijska Mosque, there are no posts in the gallery fence supporting the eaves. There are only long inclined timbers that are fixed to the main posts that support the roof. Another important detail in the two mosques that deserves attention is the access to the galleries. In the old illustrations from 1899 [13], there were simple wooden steps (basamak) that led to the gallery. Unfortunately, they were not built in the same places during the last reconstructions. A closer look at the photograph of the Džindijska Mosque (Fig. 7) also shows that this building had a minaret lined with wooden lath in a herringbone pattern, which in turn is not seen in the illustrations brought by Meringer. This confirms the assumption that this method of lining wooden minarets was also present in Tuzla. Whether the minaret of the Mejdanska Mosque was lined in the same way, we can only speculate. However, considering that conception of the porch with the gallery as well as the shape of the roof influenced the shape of the Mejdanska Mosque, it is quite certain that the minaret had the same lining.

The two mosques could have been built within a maximum of forty-four years one after the other. In so many years, it is certain that another generation of carpenters built a newer mosque. Although smaller mosques with wooden minarets already existed in the nearby mahalas on the left side of the Jala River, it can still be argued that the Džindijska Mosque had been a role model for the builder of the Mejdanska Mosque, although it was located on the opposite side of the seventeenth century palanka. Although two mosques share common features with many examples throughout Bosnia and Herzegovina, it is certain that there are peculiarities in the construction of the porch with a gallery, as well as in the shape of the roof. These qualities are the result of the inventiveness and ability of the local builder. 


\section{Conclusion}

Mahala mosques with wooden minaret exemplify authentic building tradition in Bosnia and Herzegovina during the Ottoman period (1463-1878). Concerning several factors that affected their past and present existence and usage, particularly deterioration and limited maintenance of perishable materials, these sensitive structures require constant valorization and legal protection in order not to gradually disappear. Based on the analysis of typical examples in Bosnia and Herzegovina, the study shows the authentic values of typical mahala mosques with the wooden minaret. These modest mahala mosques were built equally throughout the entire Ottoman period. The analysis showed four characteristic types: with a porch, with a gallery above the porch, with a walled vestibule, and without any entrance space. The analysis showed that there are only two mosques with a wooden porch consisting of extended galleries on three sides, while only one mosque had an extended gallery, but only on the front side. Having unique extended galleries on three sides of the porch, the Džindijska and the Mejdanska Mosque in Tuzla represent distinctive examples of the cultural identity and continuity in their environment. Thanks to continuous use and past interventions, these two mosques serve as the unique trace of the past in the current urban environment. Their last renovations are characterized by the intention to bring their earlier and appropriate appearance back. As a specific segment of the heritage, small mahala mosques require continuous observation and systematic research and valuation. To maintain their authenticity, as well as to ensure their usage and exposure in their surroundings, this study also demonstrated that these structures can be preserved with sustainable methods and common principles of restoration and conservation, with due respect to the contemporary context.

\section{References}

[1] A. Bejtić, "Banja Luka pod turskom vladavinom, arhitektura i teritorijalni razvitak u XVI I XVII vijeku," Naše starine I, pp. 91-116. 1953.

[2] A. Bejtić, "Povijest i umjetnost Foče na Drini," Naše starine III, pp. 23-75, 1956.

[3] A. Bejtić, "Spomenici osmanlijske arhitekture u Bosni i Hercegovini," Prilozi za orijentalnu filologiju, vol. III-IV, Orijentalni institut u Sarajevu, 1953.

[4] A. Handžić, Tuzla i njena okolina u XVI vijeku, Sarajevo: Svjetlost, 1975.

[5] A. Nametak, Islamski kulturni spomenici Turskog perioda u Bosni i Hercegovini, Državna štamparija u Sarajevu, 1939.

[6] B. Zlatar, "Uticaj primorskih majstora na izgradnju nekih objekata u Bosni i Hercegovini u Osmansko doba," Znakovi vremena, no. 20, pp. 68-71, 2003.

[7] Dž. Čelić, "Uticaj Turaka na matrijalnu kulturu jugoslavenskih naroda," Zagreb: Enciklopedija Jugoslavije, vol. 8, pp. 402-408, 1971.

[8] H. Redžić, Studije o islamskoj arhitektonskoj baštini, Sarajevo: Veselin Masleša, 1983.

[9] M. Bećirbegović, Džamije sa drvenom munarom u Bosni i Hercegovini, Sarajevo: Veselin Masleša, 1990.

[10] M. Kadić, Starinska seoska kuća u Bosni i Hercegovini, Sarajevo: Veselin Masleša, 1967.

[11] M. Mujezinović, Islamska epigrafika Bosne i Hercegovine, vol. 1, Sarajevo: Veselin Masleša, 1974.

[12] R. Hadžimehanović, "Ljetopis tuzlanskih džamija," in Takvim, S. Smajkić, Ed. Sarajevo: Udruženje Ilmije, 1982, pp.106-142.

[13] R. Djedović, "Meidan (Vaiz) mahala u Tuzli krajem 19. stoljeća”, Baština Sjeveroistočne Bosne, Tuzla, no. 8, pp. 85-107, 2016.

[14] R. Meringer, "Pučka kuća u Bosni i Hercegovini”, Glasnik Zemaljskog muzeja u Bosni i Hercegovini, Sarajevo, Apr-Sep 1899. [Online]. Available: http://www.infobiro.ba/article/526858

[15] Š. S. b. F. Kemura, "Sarajevske džamije i druge javne zgrade turske dobe", Glasnik Zemaljskog muzeja u Bosni i Hercegovini, vol. XX-XXIII, Sarajevo, 1908-1911. [Online]. Available: https://dlscrib.com/queue/sarajevske-d-382-amije-i-druge-javne-zgrade-turske-dobe-kemura-scaronejh-sejfuddin-fehmi-bin-ali

1913_58712eaa6454a7543235c308_pdf?queue_id=59d29ff908bbc5a162686ec3 